\title{
Directive Speech Acts in Academic Discourse: Ethnography of Communication from Gender Perspective in Higher Education
}

\author{
Fatma ${ }^{1,2}$, Harun Joko Prayitno ${ }^{3}$, Norliza Jamaludin ${ }^{4}$, Gautam Kumar Jha ${ }^{5}$, Taha \\ Ibrahim Badri ${ }^{6}$ \\ ${ }^{1}$ Faculty of Teacher Training and Education, Universitas Sebelas Maret, Indonesia \\ ${ }^{2}$ Accounting Department, STIE Panca Bhakti Palu, Indonesia \\ ${ }^{3}$ Faculty of Teacher Training and Education, Universitas Muhammadiyah Surakarta, Indone- \\ sia \\ ${ }^{4}$ Language and Communication Faculty, Universiti Pendidikan Sultan Idris, Malaysia \\ ${ }^{5}$ School of Language and Culture Studies, Jawaharlal Nehru University, India \\ ${ }^{6}$ Faculty of Language and Translation, Al Azhar University, Egypt
}

DOI: 10.23917/ijolae.v2i1.8829

Received: October $14^{\text {th }}, 2019$. Revised: October $31^{\text {st }}, 2019$. Accepted: November $1^{\text {st }}, 2019$.

Available Online: November $7^{\text {th }}, 2019$. Published Regulary: January $1^{\text {st }}, 2020$.

\begin{abstract}
In spoken academic discourse, there are various directive speech acts forms and strategies both formal and informal. Based on the previous research with different focuses show that directive speech acts is one of speech acts types mostly used in daily conversation. The study of directive speech acts can also be found in classroom interaction as spoken academic discourse. The locutors' and interlocutors' expressions in spoken academic discourse are vary. Language variation involves direct and indirect strategies as well as literal and non-literal with small portion of local language use. The use of directive speech acts is affected by contextual socio-cultural factors within the conversation. The locutors sometimes use local language in conveying certain meaning to the interlocutors. The structure of dialogue, moreover, disallows the taking up of any position beyond the interlocutors from which they can be integrated into a larger totality.
\end{abstract}

Keywords: speech acts strategy, directive speech acts, ethnography of communication, gender

Corresponding Author:

Fatma, Accounting Departement, STIE Panca Bhakti Palu, Indonesia.

e-mail:fatma@stiepbpalu.ac.id

\section{Introduction}

In order to investigate how graduates use language to convey directive speech acts, sociopragmatic study is needed. This study aims to investigate whether there is an illocutionary difference or not on each local language used in relation with the use of direct and indirect directive speech acts generating directive speech acts in spoken academic discourse represented on the local languages being used. Language besides as a means of communication, it also resembles the locutors' identities. The diversity of language usage including among the local languages used by lecturers and students is one of the linguistic phenomena that is unique in representing an intention, either implicitly or explicitly. Thus, based on this, a fundamental study is needed to reveal the uniqueness of the possible use of each local language

In spoken discourse, often someone uses indirect way to convey meaning. This notion has been studied by Hassanova and Rzayev (2013) who discuss one of the indirect strategies in pragmatics to get an answer of 
"yes" or "no" within a class interaction. By using philosophy of communication theory, sometimes someone uses interogative form and yes/no responses as indirect way to express directive speech acts. There are several factors underlying this choice: social status, superiority and inferiority, pride, and face principles. These factors become the fundamental notion that there is a pragmatic meaning in every utterance within communication to convey certain meaning.

In academic context, direct and indirect communication also become a concern. According to Ingram dan Elliot (2016:37), classroom interaction discourse is dominated by between the teacher and students, or lecturer and graduates. Classroom interaction discourse is marked with initiation, students' responses, and feedback. These processes result in several norm shifts within the class including the language choice.

The use of illocutionary acts especially directive ones whether direct or indirect sometimes make an utterance have pragmatic meaning, emotive implication, and different responses. O'Driscoll (2013), in his research about the role of language viewed from interpersonal pragmatic side, states how language can simply be understood and can be analyzed further from several linguistic aspects. This notion is in line with the development of pragmatics which is more on conversational interaction analysis based on macro-social context. This shows that the use of local language also has a gap to be studied in terms of directive speech acts.

The subjects were chosen based on the diversity of language, age, intimacy, gender, cultural background, ethnic, and dialect. Hopefully, they could emerge the diversity of directive speech acts in the use of local language. Besides, these two colleges have Bahasa Indonesia study program, so the use of local language among lecturer and graduates can be investigated further. In this case, socio-cultural context is seen as a dynamic context that affects the directive strategies in spoken academic discourse with multicultural background.

Based on the literature review, studies on directive speech acts are focused more the use of Bahasa as a single language on certain society and it is usually a case study. On the previous studies, quantitative study was held in society and school context by using test, questionnaire, and survey with single data analysis approach; for example discourse analysis, pragmatic, and sociolinguistic approach.

The other gap is related to how a certain interaction has an important role by using local language as the choice of words in communication. Therefore, sociolinguisticpragmatic approach is used to reflect the social relationship between the locutors and interlocutors in order to interpret the implied meaning of their conversation. As stated by Turner (in Darmojuono, 2011: 20) that in a multilingual and multicultural society, language, as a means to convey verbal meaning, reflect the indentity of the locutor based on the socio cultural norms and values they hold on within the society.

Previously, several research focus on the study of Bahasa Indonesia instead of local languages. The class interaction discourse of this research involves several local languages, such as: Kaili, Malayan Bugis, and Malayan Manado.

This research is focused on the three regional languages, with the consideration that the three regional languages are the local languages, the majority of which are used in Palu, Central Sulawesi, both in the academic realm and in daily life. In addition, Kaili, Bugis Malay and Manado Malay are local languages that are intertwined with "kinship languages" even though they are very 
different and are not allied languages. The role of the three languages. The Kaili language is the regional language used by the Kaili tribe which is the majority ethnic group in Central Sulawesi. Bugis is a language whose native land originated from Sulawesi Island. The Bugis language is one of the regional languages used by the Bugis tribe originating from South Sulawesi whose numbers are very dense and then spread to most areas in Central Sulawesi due to population movements and marriages. The Kaili language is the regional language used by the Kaili tribe which is the majority ethnic group in Central Sulawesi. The Manado language is a lingua franca in North Sulawesi and is considered a regional dialect of Malay. The use of Manado language coexists with local languages, Indonesian, and foreign languages that have spread to several regions including Central Sulawesi due to population mobility and cultural acculturation (Imbang, 2014: 21).

\section{Method}

This research is a qualitative study with ethnography of communication approach by using Hymes' SPEAKING. Pragmatic and ethnographic views are used to discern the more specific 'local' conditions especially on the cooperative and politeness principles among the lecturer and the graduates as well as in the way they use direct and indirect strategies. In this research, not all utterance elements are used to expound the problems. The communicative design in this research perspective is based on the use of language contextually which have social communicative function (Mudiono, 2011: 162). Context plays an important role in this study, for it eases the pragmatic analysis.

Context used in this study involves extralinguistic and linguistic context. Extralinguistic context relates to socio cultural aspects, while linguistic context relates to the language being used. Praag, Stevens, dan Houtte (2017: 393), in their research, state that in order to achieve the communication goal, locutors have to use utterance strategies and interpretation. Therefore, the use of ethnography of communication method and gender perspective become the main features to investigate every cultural background and social norms like education level, gender, social status, intimacy, and the others.

This research uses socio-pragmatic approach by expounding the ethnography of communication from Hymes' point of view to interpret local language directive speech acts strategies, local language directive speech acts characteristics, diction affecting factors, as well as the effectiveness of Bahasa Indonesia with contextual minor local language combination viewed from the locutors, interlocutors, age, gender, social status, ethnic, and culture. The data collection technique is using participant observation which includes: (1) recording, (2) note taking, dan (3) interview which then analyzed by using interactive technique from Miles and Huberman.

This study uses interactive model data analysis (Miles \& Huberman, 2014: 16-20). The analysis process involves three steps: (1) data reduction, (2) data display, and (3) conclusion drawing. The data analysis is integrated with pragmatic theory, especially in classifying the directive speech acts by Searle (1967); as well as socio-pragmatic and ethnographic approaches. The acronym SPEAKING created by Hymes is related to the speech acts components in spoken academic discourse.

The socio-pragmatic approach is realized in both method and data analysis. After the spoken utterance data were collected from the lecturer's and graduates' 
interactions, data reduction was done through data selection, classification, and simplification process. Afterwards, the variety of strategies found in the field is reported.

\section{Result and Discussion}

a. Local Language Directive Speech Acts Strategies in Spoken Academic Discourse in Central Sulawesi Higher Education

The following is the expounding on the use of local language strategies found in the field. The expounding covers direct and indirect strategies together with their forms.

\section{1) Local Language Directive Speech Acts Direct Strategy}

Interaction pattern in spoken academic discourse raises communication strategy variation shown through politeness, modesty, appreciation, and respect among the lecturer and the graduates inside the class. Using effective communication strategies inside the class is beneficial in achieving teaching and learning goals. Effective communication can describe meaning form interlocutor and receive cultural languages background. That is why sometimes, lecturer and student need to use local language in teaching processing. Processing language with local language and dialect really important to show politeness, ages, social distances and how to create some classes focus and how to have a critical language with each other. Using strategies language can help teacher or student know some deeper meaning.

For example, Keckskes, Obdalova, Minakova, and Soboleva (2018: 228) find that giving respect, compliment, as well as sympathy gives the sense of pleasure and happiness both the locutors and interlocutors which eventually can minimize interactional problems, burden, disagreement, and the other disregarding actions. This finding is in line with Alexander \& Okoli's finding (2017: 148) which shows that the act of giving chance to speak up among participants can trigger them to use speech act of the language they master, local language. Meanwhile, the direct strategy forms obtained in the language subjects, Kaili, Malayan Bugis, and Malayan Manado, are: request, suggestion, command, refusal, and prohibition.

\section{a) Direct Strategy in Directive Speech Acts of Request in Kaili}

The Kaili direct directive speech acts of request used in the above conversation is marked by the use of word tambaimo which means asking for further or detailed explanation. The above data also show the use of Kaili vocatives like Totuamo dan Komiu, nadoyo which mean 'elderly,' 'you,' and 'outstanding' (the real meaning is 'incorrect' and 'stupid'). Fomin dan Yakimova (2016: 66) find that someone can express requesting in three different ways: cooperation, refusal, and showing distance. These three choices are also affected by age, social background, and the underlying reasons in choosing words. The above finding shows the use of cooperation by expressing certain vocatives. The use of vocatives affects the form of the speech acts which eventually results in the cooperation between the locutor and interlocutor.

The vocatives were used in direct requesting to let his graduate friend, who is also an elementary teacher, on [1.1] and [1.3] which translate please answer the question, Ma'am, since you're more experienced than us. At the end of the request, he praised his friend by using nadoyo in sentence (5). The word does not mean any praise. Lakoff (1990:34) states that politeness is an interpersonal relationship system designed to 
ease interaction and minimize conflict and Perspective in Higher Education

confrontation by using implicative utterance context.

Table 1. Direct Strategy in Directive Speech Acts of Request in Kaili

\begin{tabular}{|c|c|c|c|c|}
\hline No & Lo-In & Strategy Form & Bahasa Indonesia & English \\
\hline [1] & $\begin{array}{l}\text { Loc } \\
(\mathrm{dsn})\end{array}$ & $\begin{array}{l}\text { Bemana mangkali Totuamo } e \text {, } \\
\text { tambai mo Bu. Anu ri jelaskan } \boldsymbol{i} \\
\text { hei } i .(1)\end{array}$ & $\begin{array}{l}\text { Bagaimana } r \text { mungkin } \\
\text { orangtua saja, tambahkan } \\
\text { saja, Bu. Mau dijelaskan } \\
\text { seharusnya. }\end{array}$ & $\begin{array}{l}\text { Ma'am, you are older } \\
\text { than us, so please add } \\
\text { this. This should be } \\
\text { explained first. }\end{array}$ \\
\hline [2] & Mod & Please! & & \\
\hline \multirow[t]{4}{*}{ [3] } & Pn & $\begin{array}{l}\text { Apa lebe lagi Ibu dari kitorang } \\
\text { ranga. }\end{array}$ & $\begin{array}{l}\text { Karena lebih lagi Ibu dari } \\
\text { kami ini. }\end{array}$ & $\begin{array}{l}\text { 'Since she (Ibu) is } \\
\text { smarter than us.' }\end{array}$ \\
\hline & In & (gives explanation) & & \\
\hline & Mod & $\begin{array}{l}\text { Mantap, mantap } \\
\text { (bertepuktangan) }\end{array}$ & $\begin{array}{l}\text { Bagus, } \\
\text { (penjelasannya) } \\
\text { (bertepuktangan) }\end{array}$ & $\begin{array}{l}\text { Your explanation was } \\
\text { simply outstanding, } \\
\text { Ma'am. (applausing) }\end{array}$ \\
\hline & Lo & Nadoyo, leh & Luar biasa. & $\begin{array}{l}\text { Outstanding (based on } \\
\text { the context, it undergoes } \\
\text { amelioration) }\end{array}$ \\
\hline
\end{tabular}

Uttered by an graduate to the other graduate asking for help to explain further during $\mathrm{Q} \& \mathrm{~A}$ session in a discussion.

which literally harsh becomes soft due to the 
clarity, seriousness, and purpose of communication.

The use of speech acts inside the classroom sometimes happens naturally by considering the communication effectiveness and accuracy, coverage, and face unthreatening power; whether lecturer to graduates, graduates to lecturer, or graduates to graduates. Positive politeness is done by giving sympathy and appreciation towards situation and condition within the class, using group identity markers, showing agreement, avoiding disagreement, showing intimacy, giving a joke, expressing wants indirectly, involving the graduates, and giving feedback.

The assumption is that in reality each form of communicative communication choice is based on how the languages are used in social contexts. In this communication there are a number of aspects of the said situation that must be considered, namely: (1) speech-speakers, the situation in communication involves the speaker and speech partner so that this element is included in the part of communication, (2) the context of the speech; the context is a background of knowledge that is shared by the speaker and the speech partner and speech partner, (3) the purpose of the speech.

This is intended as a desire to be achieved by the speaker and the speech partner, (4) the speech as a form of action, that the speech is aligned with the illocutionary act, and (5) the speech as a verbal act product; speech that is used as found in the fourth aspect is a form of speech act so that speech is a form of verbal action Direct strategy in directive speech acts of request in Malayan Bugis can be seen Table 2.

For example in an occassion, lecturer mentions graduates with their nicknames; besides, it makes the graduates feel respected, it also makes the lecturer and the graduates closer. This condition encourage the graduates' confidence and comfortability in joining the class. Politeness is believed to be able to develop effective interaction between locutor and interlocutor. Furthermore, this condition is mostly affected by each participant's cultural context. Cultural context affects politeness concept, form, and strategy (Rahman \& Jabar, 2014:374).

In social interaction, in order to maintain politeness, ones tend to keep the harmony and continuity of the interaction and hinder any harmful utterance which can threaten the face to the existing norm. In classroom context, lecturer and graduates utter not only for explaining, advising, motivating, giving information, but also for maintaining interpersonal relationship by concerning on each other's faces. The choice of communication strategy is influenced by several factors, namely social status, superior and inferior, maintaining dignity, and selfesteem. This is a benchmark that in reality there is a relationship between meaning and pragmatic power. Direct and indirect communication strategies in the academic community are also of particular concern. In line with this in the Indonesian language academic activities, aspects of the cultural context are inseparable in order to convey certain meanings. 
Table 2. Direct Strategy in Directive Speech Acts of Request in Malayan Bugis

\begin{tabular}{|c|c|c|c|c|}
\hline No & Lo-In & Strategy Form & Bahasa Indonesia & English \\
\hline [1] & Lo & $\begin{array}{l}\text { Bu e tunggu Bu jolo'pi } \boldsymbol{e} \\
\text { belumpa selesai mencatat. }\end{array}$ & $\begin{array}{l}\text { Ibu tunggu dulu ya, belum } \\
\text { selesai mencatat saya. }\end{array}$ & $\begin{array}{l}\text { 'Ma'am, wait a sec. I } \\
\text { haven't done taking notes.' }\end{array}$ \\
\hline [2] & In & Yang mana $e ?$ & Yang mana? & 'Which one?' \\
\hline [3] & Lo & Masih banyak $J e \mathrm{Bu}$ eh. & Masih banyak ini Ibu. & 'So many, Ma'am.' \\
\hline [4] & In & $\begin{array}{l}\text { Sebentar pi, salendianya } \\
\text { maujie digandakan sama } \\
\text { bapak. Lebbirengngi matu'pi } \\
\text { mucatat ndi. Mintami nanti, } \\
\text { lambatmi ini. }\end{array}$ & $\begin{array}{l}\text { Sebentar saja. Salindianya } \\
\text { mau juga digandakan sama } \\
\text { Bapak. Sebaiknya nanti saja } \\
\text { kamu catat, Dik. Minta saja } \\
\text { nanti. Sudah lambat ini. }\end{array}$ & $\begin{array}{l}\text { 'Wait, the slides are going } \\
\text { to be copied by Bapak. } \\
\text { Better you write down } \\
\text { after this. You can ask for } \\
\text { (the slides) later, it's been } \\
\text { too late.' }\end{array}$ \\
\hline [5] & Lo & $\begin{array}{l}\text { Bu, kita mi barangkali yang } \\
\text { minta ke Bapak. Takut- } \\
\text { takutka saya deh Bu. }\end{array}$ & $\begin{array}{l}\text { Bu, ibu saja yang meminta ke } \\
\text { Bapak, saya takut }\end{array}$ & $\begin{array}{l}\text { 'Please Ma'am, ask for (the } \\
\text { slides) to Bapak. I'm afraid } \\
\text { doing that.' }\end{array}$ \\
\hline [6] & In & Tidak apa itu canti & Tidak apa, cantik. & $\begin{array}{l}\text { 'Don't be afraid, Sweety } \\
\text { (just ask the copies from } \\
\text { him).' }\end{array}$ \\
\hline
\end{tabular}

Context The first part was uttered by the graduate, who hadn't completed writing down the materials, to the lecturer. The second was uttered by a graduate to her friend.

Code SL/TTD.srn/09.01.17/01

* Lo: Locutor \& In: Interlocutor

The direct strategy used in data [2.4] is in the form of advising. The use of advise is marked by the use of verb lebbirengngi which means 'better.' In that context, the advise is from a graduate to his friend who was late to write down the slides. To avoid the sense of commanding, the locutor, who is older than the illocutor, tried to use vocative ndi' which means dik (little brother) in Bugis. The advising form depends to the locutor's intention towards the illocutor. The use of vocative $n d i$ ' and formal vocative canti which means beauty show the intimacy of the participants which are used to show politeness in giving advise.

Kridalaksana (in Agus, 2014: 3) states that vocatives are used in speech system. The use of vocatives affects the structure and the context. If the vocatives stand alone, the meaning is not a praise or appreciation. The appropriateness of vocative depends on the context. In social context, the use of vocative is regarded as a communication strategy that encourage the social relationship among participants. In its implementation, the use of vocative is adjusted with the participants' social status (Agus, 2014:4).

Besides functioning as linguistic marker, the use of vocatives also shows the level of intimacy among the participants as shown previously. Lohse, Granefenhain, Behne \& Racoczy (2014:2) state that the use of imperatives depends on the shared context between the locutor and interlocutor.

\section{c) Direct Strategy in Directive Speech Acts of Command in Malayan Bugis \\ The politeness is shown in formulating} requesting direct strategy used by the locutor to his friend. The commanding form on the data above is expressed by explicitly. Requesting form in Bugis language is 
affected by social points of view (social power, intimacy, and distance), so different participants will result in a different way of communication. On the above data [3.2] politeness marker is shown by the use of words $\boldsymbol{k} \boldsymbol{a}$ ' and $\boldsymbol{t a}$, or actually can use-ko as a coeval vocative. The use of honorifics in the Bugis Malay language proves that the use of regional languages is influenced by age and who the speech partner is. The use of regional languages is used to show respect by students for lecturers. Previously, the form of politeness was first used by lecturers towards students by using indirect speech in the command. The age factor becomes the choice factor why local languages are used. If the speakers are peers. Then the choice of the form of regional languages used can be iyo (yes) in the Kaili and Malay Manado languages or it can even be in the form of murmurs, for example in the form of lingual expressions which mean ok or good.

Table 3. Direct Strategy in Directive Speech Acts of Command in Malayan Bugis

\begin{tabular}{lllll}
\hline No & Lo-In & \multicolumn{1}{c}{ Strategy Form } & Bahasa Indonesia & \multicolumn{1}{c}{ English } \\
\hline$[1]$ & Lo & $\begin{array}{l}\text { Hubungimi dulu Ibu apa'na } \\
\text { terlambatki lagi nanti masuk } \\
\text { matakuliah kedua }\end{array}$ & $\begin{array}{l}\text { Hubungi dulu Ibu, sebab } \\
\text { terlambat kita nanti masuk } \\
\text { matakuliah kedua. }\end{array}$ & $\begin{array}{l}\text { 'It's better we notify you first, } \\
\text { Ma'am, since probably we will } \\
\text { come late for the second class.' }\end{array}$ \\
& [2] & $\begin{array}{l}\text { Pinjamka' pale dulu hp } \boldsymbol{t a} \\
\boldsymbol{e}\end{array}$ & Pinjam saya HP kamu & $\begin{array}{l}\text { 'I borrow your cell phone, } \\
\text { OK?' }\end{array}$
\end{tabular}

Context Uttered by a graduate to his friend while they were going to call their lecturer.

Code SL/TTD.pth/05.01.17/01

Stranovskȧ, Munkova, Fräterova, \& Duračkovã (2013) find the politeness aspects in Slovakian and other foreign language requesting in cognitive context, that speech acts elements to maintain politeness are determined by social distance among the participants. It is shown in table [3.2] above, the interaction between two graduates. Indirectly, the use of local language can help the lecturer and graduates to obey the existing linguistic norms like how to refer each other well; express respect, gratitude, forgiveness, permission; and ask for help. The other important pragmatic element in studying spoken discourse is cooperative principles. Hiver \& Whitehead (2018:197) states that the quality of language use can be seen from several aspects: content, genre, topic, topic organization, sequences and rules of the conversation.

\section{d) Direct Strategy in Directive Speech Acts of Refusal in Malayan Manado}

The implemented strategies are to develop interpersonal relationship among graduates which are eventually used to make the graduates active during the class. One way to implement the interpersonal principles to do communication is by using politeness strategy (Yetiș \& Aslim, 2010: 447). To understand a classroom discourse comprehensively, every activity in the classroom is related to cooperative principles, interactional pattern, contextual and cultural meaning among the participants. Interactional pattern underlined by the cooperative principles occuring between lecturer and graduates are in the form of speech acts. Sirkovic \& Kovac (2017: 115) state that communication strategy by using speech acts enable to maintain the principles and or even break them instead as per to the 
participants' communication purposes. The word so on data [4.1] is an indirect emphasis used by the interlocutor to say that the discussion, because the time is already at 3 p.m.

The indirect strategies are supported by the use of modal marking prohibition nyanda' which mix in the requesting sentence in order to state that there will be no more sessions and Manado word jang as prohibition marker as a refusal to the extension of the session. The following data [4] show the use of both directive speech acts of refusal and command.

Table 4. Direct Strategy in Directive Speech Acts of Refusal in Malayan Manado

\begin{tabular}{|c|c|c|c|c|}
\hline No & Lo-In & Strategy Form & Bahasa Indonesia & English \\
\hline [1] & Lo & $\begin{array}{l}\text { So jam berapa ini ranga? Ada } \\
\text { mangkali jam } 3 \text { ini. }\end{array}$ & $\begin{array}{l}\text { Sudah pukul berapa } \\
\text { ini? Barangkali ini } \\
\text { sudah ada pukul } \\
15.00 ?\end{array}$ & $\begin{array}{l}\text { 'what time is it? } 3 \\
\text { p.m.? }\end{array}$ \\
\hline [2] & In & $\begin{array}{l}\text { So boleh sudah itu! Nyanda' pake } \\
\text { lagi. Jang ditambah. }\end{array}$ & $\begin{array}{l}\text { Sudah boleh sudah itu } \\
\text { (diskusi). Tidak pakai } \\
\text { lagi. Jangan ditambah. }\end{array}$ & $\begin{array}{l}\text { 'Enough, the } \\
\text { discussion ends here. } \\
\text { No more session. Let's } \\
\text { stop.' }\end{array}$ \\
\hline [3] & Mod & (Ends the discussion) & & \\
\hline & Context & \multicolumn{3}{|c|}{ Uttered by a graduate to his friend to end the class discussion. } \\
\hline & Code & SL/TTD.plk/12.01.17/01 & & \\
\hline
\end{tabular}

e) Direct Strategy in Directive Speech Acts of Prohibition in Malayan Manado

Maintaining or breaking the cooperative principles arises various politeness forms used by the participants. In order to understand the meaning and intention of the participants, each of them has to relate the utterance to the context and context. The framework of this case is that analyzing a text requires the analysis of the time, place, and the participants involved, as well as the background of the information. In communication design studies, the most important factor of communication is context (Kruiningen, 2013: 118). Context is known as shared knowledge between locutor and interlocutor which helps in the process of interpretation.

The use of words so dan nyanda' on data [5.4] show directive srategy of refusal and prohibition in Malayan Manado. Refusal marker is marked by the word so in sentences (1) and (2) to express unwillingness towards what the others' wants. This refusal supports prohibition in sentences (7) and (8) by using words nyanda and jang which mean 'no' and 'don't'. This use is as per to the commanding speech acts classified by Ramlan (2001) which divides imperative sentence into: (1) true imperative, (2) allowance imperative, (3) invitational imperative, and (4) prohibiting imperative. Conditions that support involve the reality of the actions and abilities of the interlocutor. For an order, to be able to meet the conditions of possible time conditions, the speech partner must accept the authority of the speaker, for example for a request, the expectation of the speaker, and for a suggestion, as well as the evaluation of the speaker. Felicity conditions of a directive 
speech act are the ability of the speech partner to do something according to the feasibility of the action. Just like other types of speech acts, a directive speech act presumes certain conditions exist in the interlocutor and in the context of the situation. When words can be realized, it means that the atmosphere supports and if it does not materialize means it does not support. Thus, in general directive indices can be categorized into four general forms, namely, imperative forms, requests (requests and requests), suggestions, and prohibition.

Keraf (1991:158) expounds that imperative sentence is a sentence showing command or request towards the others to do something as per to the intention of the locutor. One of the forms is prohibition. Alwi, Dardjowidjojo, Lapoliwa, \& Moeliono (2003:336) similarly state that imperative sentence in Bahasa includes: (1) intransitive imperative, (2) transitive imperative, (3) soft imperative, (4) requesting imperative, (5) allowance imperative, (6) prohibiting imperative, and (7) permitting imperative.

The form of imperative in data [5.4] is included as soft imperative with indirect strategy which is ended with direct imperative. With contextual understanding skill, graduates and the other discussion participants deal to conclude the discussion.
This situation could happen since there is no domination from any participant also there is a common understanding over the situation among them. This case, relevant with the presentation of findings and study studies in the field of politeness in language by Prayitno, Kusmanto, Nasucha, Rahmawati, Jamaluddin, Samsuddin, Ilma $(2019,52)$ that there is the use of communication strategy choices, one of which is showing a form of politeness as a form of conflict prevention, in addition to politeness is also used by lecturers, instructors, and other social groups to form understanding in the process of communicating by upholding values and gratitude.

The success in achieving communication purposes is due to the use of direct strategy without any ado which gives positive effect over the communication effectiveness and accuracy (Harman, Ahn, \& Bogue, 2016: 210). Moreover, it is affected by the level of social distance, lecturer's power, and faceunthreatening language. The politeness tends to be positive as shown on the way they show appreciation, use vocatives, show agreement, avoid disagreement, show intimacy, give a joke, show indirect want, involve locutor and interlocutor, and give feedback.

Table 5. Direct Strategy in Directive Speech Acts of Prohibition in Malayan Manado

\begin{tabular}{|c|c|c|c|c|}
\hline No & Lo-In & Strategy Form & Bahasa Indonesia & English \\
\hline [1] & Mod & $\begin{array}{l}\text { Kita akan mendengarkan hasil } \\
\text { diskusi kita hari ini oleh } \\
\text { Notulis dan selanjutnya akan } \\
\text { dikuatkan oleh } \text { dosen } \\
\text { pengampu matakuliah. . Ebe } \\
\text { jang baribut ranga! } \\
\text { Perhatikan dulu! }\end{array}$ & $\begin{array}{l}\text { Kita akan mendengarkan hasil } \\
\text { diskusi hari ini oleh Notulis dan } \\
\text { akan diperkuat oleh dosen } \\
\text { pengampu matakuliah. Coba jangan } \\
\text { ribut. perhatikan dulu! }\end{array}$ & $\begin{array}{l}\text { 'We will listen } \\
\text { the result of the } \\
\text { discussion read } \\
\text { from the MoM } \\
\text { (minutes of } \\
\text { meeting) which } \\
\text { then will be } \\
\text { explained } \\
\text { further by the } \\
\text { lecturer. Please } \\
\text { don't be noisy. } \\
\text { Attention } \\
\text { please! }\end{array}$ \\
\hline
\end{tabular}




\begin{tabular}{|c|c|c|c|c|}
\hline No & Lo-In & Strategy Form & Bahasa Indonesia & English \\
\hline [2] & MoM & $\begin{array}{l}\text { (MoM recorder reads the } \\
\text { result of the discussion) }\end{array}$ & & \\
\hline [3] & Lo & Season ketiga, boleh? & Sesi ketiga, boleh? & $\begin{array}{l}\text { 'Am I allowed } \\
\text { to ask question } \\
\text { (again) in the } \\
\text { third session?' }\end{array}$ \\
\hline [4] & Mod & $\begin{array}{l}\text { So nyanda' pake season } \\
\text { ketiga lagi. } \\
\text { ditambang }\end{array}$ & $\begin{array}{l}\text { Sudah tidak pakai sesi ketiga lagi. } \\
\text { Jangan lagi ditambah. }\end{array}$ & $\begin{array}{l}\text { 'Enough (the } \\
\text { discussion } \\
\text { session). Time is } \\
\text { up already } \\
\text { (muttering)!' }\end{array}$ \\
\hline [5] & In & $\begin{array}{l}\text { So boleh e. So jam } 3 \text { dan ini. } \\
\text { (menggerutu) }\end{array}$ & $\begin{array}{l}\text { Sudah boleh. Sudah Jam } 3 \text { ini } \\
\text { (menggerutu) }\end{array}$ & $\begin{array}{l}\text { 'Enough (the } \\
\text { discussion } \\
\text { session). It's } 3 \\
\text { p.m. already } \\
\text { (muttering)!' }\end{array}$ \\
\hline
\end{tabular}

Context Uttered by a graduate to the other during limited time at the end of the session wanting to question again.

Code $\quad$ SL/TTD.Irg/09.03.17/01

\section{2) Indirect Strategy in Local Language Direct Speech Acts}

Similar to the finding on direct strategy, the finding on indirect strategy is classified into request, suggestion, command, refusal, and prohibition indirect strategies in Kaili,

At glance, the conversation below [6.2] uses interrogative sentences in general, but in deeper sense, there is a request from the locutor to the interlocutor there. Without using any negation markers, based on the context developed within the conversation, the locutor expected an explanation with answer and comment. Semantically and pragmatically, the utterance means requesting. In language in a society there is the principle of politeness in speech. In this case polite and subtle in question is the information contained in the speech is not said clearly and openly, but only implicitly or implicitly. This can be seen in the data snippet which is a form of directive speech act in the Bugis language which functions as a form of advice delivered with an indirect strategy using an indirect strategy. Words
Malayan Bugis, and Malayan Manado languages.

\section{a) Indirect Strategy in Requesting Directive Speech Acts in Malayan Manado}

that indirectly indicate a suggestion are stated earlier in a question form.

Generally, each utterance can represent ones' culture. Further, utterance can also represent ones' identities. Similarly, Ogunsiji, Farinde, and Adebiyi (2012: 203) expound that the way in using language (including speech acts), interacting, showing power, and obeying interpersonal norms are different between man and woman. Man labels their speech acts as powerful speech while woman powerless speech.

In the same study, Fontdevila (2010:588) states that politeness is also used to maintain harmony and continuity of social interaction. The lecturer tends to use both positive and negative politeness. Similarly, the graduates also do the same among themselves in the effort to build cooperative 
and empathic class atmosphere which their social distance which makes the class eventually create a positive class interaction. more interesting (Peng, Xie, \& Cai, 2014). The use of politeness strategies can shorten

Table 6. Direct Strategy in Directive Speech Acts of Command in Malayan Bugis

\begin{tabular}{|c|c|c|c|c|}
\hline No & Lo-In & Strategy Form & Bahasa Indonesia & English \\
\hline [1] & $\begin{array}{l}\text { Lo } \\
\text { (male) }\end{array}$ & $\begin{array}{l}\text { Apa depe beda katu' itu puisi } \\
\text { kontemporer dulu deng sekarang, } \\
\text { Mala? }\end{array}$ & $\begin{array}{l}\text { Apa dia punya beda itu puisi } \\
\text { kontemporer dulu dengan } \\
\text { yang sekarang, Mala? }\end{array}$ & $\begin{array}{l}\text { 'Mala, what is } \\
\text { the difference } \\
\text { between classic } \\
\text { and } \\
\text { contemporary } \\
\text { poems?' }\end{array}$ \\
\hline [2] & $\begin{array}{l}\text { In } 1 \\
\text { (female) }\end{array}$ & $\begin{array}{l}\text { Ada di halaman berapa itu depe } \\
\text { penjelasan. Buka saja itu bukunya } \\
\text { W.S Rendra yang torang so kopi } \\
\text { kemarin, dang. }\end{array}$ & $\begin{array}{l}\text { Ada di halaman kesekian itu } \\
\text { penjelasannya. Buka saja } \\
\text { buku W.S Rendra yang sudah } \\
\text { digandakan kemarin. }\end{array}$ & 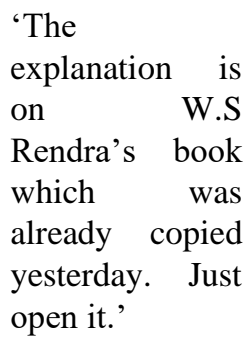 \\
\hline [3] & $\begin{array}{l}\text { In } 2 \\
\text { (male) }\end{array}$ & $\begin{array}{l}\text { Yang penting ngana pahami dulu } \\
\text { itu kontemporer koa' apa. }\end{array}$ & $\begin{array}{l}\text { Yang penting adalah kamu } \\
\text { memahami terlebih dahulu } \\
\text { apa yang dimaksud dengan } \\
\text { kontemporer. }\end{array}$ & $\begin{array}{l}\text { 'At least you } \\
\text { have to } \\
\text { understand the } \\
\text { notion of } \\
\text { contemporary in } \\
\text { literature first.' }\end{array}$ \\
\hline & $\begin{array}{l}\text { Context } \\
\text { Code }\end{array}$ & \multicolumn{3}{|c|}{ Uttered by a graduate to the other to refuse explaining further over a question. } \\
\hline
\end{tabular}

b) Indirect Strategy in Directive Speech Acts of Suggestion in Malayan Bugis

In doing communication within society, ones have to obey politeness principles. In other words, the intention of the speaker has to be conveyed implicitly. It can be seen on data [7.4] that is included as Bugis language directive speech acts functioning as a suggestion with indirect strategies. Words that implies suggestion, previously stated, were uttered in interrogative form [7.2]. Those words are wasettoni pura which mean 'I thought it ends already'. This meaning is equivalent to ' $\mathrm{O}$ not yet? I thought we've finished, so not yet, hasn't it?'

Liantada (2018:3) explains context as shared knowledge between locutor and interlocutor which helps the interlocutor to interpret the locutor's meaning. The use of Bahasa Indonesia in social interaction does not only require syntactic and semantic knowledge, but also pragmatic. Semantics relates to the knowledge about speaker's intention (Steadmen, Kayi-Aiydar \& Vogel, 2018: 40). Therefore, in order to understand locutors' utterance, the interlocutors have to understand first their communication habit and the way they express their utterance politely.

The real meaning of the utterance was suggesting to stop which was supported by words in sentence [7.4] lebbireng ditahan. Since there were other graduates that had not spoken up during the discussion, so it was 
better for the locutor to discuss further later. (1990:34) states that politeness is an It means that both the locutor and interpersonal relationship system designed to interlocutor have to understand the structure ease interaction by minimizing potential of the utterance as well as the implied conflict and problem. Implied meaning is meaning of the utterance in order to regarded as polite; it changes harsh utterance buildeffective communication. Lakoff into a soft one.

Table 7. Indirect Strategy in Directive Speech Acts of Suggestion in Malayan Bugis

\begin{tabular}{|c|c|c|c|c|}
\hline No & Lo-In & Strategy Form & Bahasa Indonesia & English \\
\hline [1] & Lo & Begini, saya mau bertanya. & Begini, saya mau bertanya. & $\begin{array}{l}\text { 'Like this, I want } \\
\text { to ask.' }\end{array}$ \\
\hline [2] & In & $\begin{array}{l}\text { Eh... belum pi pale. } \\
\text { Wasettoni pura } \mathrm{Bu}\end{array}$ & Oh, belum ya. Saya kira sudah, Bu. & $\begin{array}{l}\text { 'Oh not yet } \\
\text { (done). I thought } \\
\text { already (done } \\
\text { asking), Ma'am.' }\end{array}$ \\
\hline [3] & Lo & Torang masih bacurita. & Kami masih bercerita. & $\begin{array}{l}\text { 'We are still } \\
\text { discussing.' }\end{array}$ \\
\hline [4] & In & $\begin{array}{l}\text { Belum selesai Oo, saya kira } \\
\text { sudami bertanya kita Bu. } \\
\text { Belum pale'(tertawa). } \\
\text { Sanggadi pi Bu, ada pi lagi } \\
\text { materi nanti lebbireng } \\
\text { ditahan. }\end{array}$ & $\begin{array}{l}\text { Oh belum selesai. Besok saja, Bu. } \\
\text { Ada saja materi lagi nanti lebih baik } \\
\text { ditahan. }\end{array}$ & $\begin{array}{l}\text { 'Oh not yet } \\
\text { done, Ma'am? } \\
\text { Maybe next } \\
\text { week, Ma'am. } \\
\text { Better if there is } \\
\text { material like this } \\
\text { next time, so you } \\
\text { can save it for } \\
\text { later.' }\end{array}$ \\
\hline
\end{tabular}

Context Uttered by graduate to the other to suggest to stop questioning since the discussion has ended.

Code STL/F.srn/09.01.17/02

c) Indirect Strategy in Commending Directive Speech Acts in Malayan Manado

Kunjana (2005:36) classifies imperative sentence in Bahasa Indonesia into: (1) normal imperative, (2) requesting imperative, (3) allowance imperative, (4) invitational imperative, and (5) commanding imperative. To refuse certain command, sometimes interlocutor (In) uses strategy to recommand the locutor (Lo) as shown in the conversation below.

The locutor's utterance is imperative formulated in the form of declarative sentence. The imperative marker on the conversation below [8.1] does not simply inform but make the interlocutor to do what the locutor wants to do. The refusal meaning is also supported by the context which includes the place, topic, and participants. On their findings, $\mathrm{Su}$ (2017: 72) and Pallawa (2013: 176) state that linguistic choice used in speech acts can vary.

Based on the context, the use of local language on the conversation above gives more pragmatic implication to the interlocutor. The use of local language resembles the multilingualism of Bahasa and as an effort to preserve it. Moreover, the use of local language in informal situation does not harm the linguistic norm. The use of language in communication is strongly 
influenced by participant culture (Harman \& Dobay: 2012: 4). Based on this, a person's cultural background can influence the communication process. In oral communication, it can reflect the belief systems and norms developed in a society.
Communities of dialect users each have differences in the delivery of language as a medium of communication, including regional languages, used to convey goals and meanings communicatively to participants.

Table 8. Indirect Strategy in Commending Directive Speech Acts in Malayan Manado

\begin{tabular}{|c|c|c|c|c|}
\hline No & Lo-In & Strategy Form & Bahasa Indonesia & English \\
\hline [1] & Lo & $\begin{array}{l}\text { Tinggal sadiki ini kupon } \\
\text { torang mo bikin apa }\end{array}$ & $\begin{array}{l}\text { Kuponnya tinggal sedikit lagi. Kita } \\
\text { mau bikin apa? }\end{array}$ & $\begin{array}{l}\text { 'The remaining } \\
\text { coupons are not } \\
\text { many. What } \\
\text { should we do?' }\end{array}$ \\
\hline [2] & In & $\begin{array}{l}\text { Kase akang yang laeng jo. } \\
\text { Jang kita. }\end{array}$ & $\begin{array}{l}\text { Berikan yang lain saja kuponnya. } \\
\text { Jangan saya. }\end{array}$ & $\begin{array}{l}\text { 'Give to the } \\
\text { other, do not } \\
\text { give it to me } \\
\text { (again).' }\end{array}$ \\
\hline [3] & Lo & $\begin{array}{l}\text { Baku ganti lah kan torang } \\
\text { te apa! }\end{array}$ & Saling ganti lah kita tidak apa. & $\begin{array}{l}\text { 'We can take } \\
\text { turn (to sell the } \\
\text { coupons), right? }\end{array}$ \\
\hline [4] & In & $\begin{array}{l}\text { Lihat tugas masing-masing } \\
\text { jo. Nyanda salah ngana } \\
\text { bilang pa kita itu! }\end{array}$ & $\begin{array}{l}\text { Lihat tugas masing-masing saja. } \\
\text { Tidak salah kamu bilang ke saya } \\
\text { itu. }\end{array}$ & $\begin{array}{l}\text { 'Just do our own } \\
\text { job! You cannot } \\
\text { say like that.' }\end{array}$ \\
\hline
\end{tabular}

Context A graduate indirectly asked her graduate friend to help her sell the class bazaar coupons by offering the coupons to his friend.

Code $\quad$ STL/F.pth/13.03.17/01

Language consists of two elements, structure and meaning. Naturally, language is a means to convey meaning to the others in an understandable way. Suparto (2017: 76) states that meaning is dependent towards perception. Locutor's knowledge roles importantly in creating meaning. Context and context are vital in understanding the locutor's meaning and intention. In other words, in order to analyze a text, besides understanding the structure, ones have to understand the place, time, and participants and the background of the utterance. Mey (2001: 39) opines that context is a dynamic notion not static that helps participants during communication. By the context, linguistic expression can be understandable.
At glance, the above conversation has no related meaning between Lo's and In's utterances, yet based on the context it can be seen that Lo asked In to sell the remaining coupons on sentence [1] which then replied by In by commanding back with indirect strategy. Lo is a woman while In is a man. Refusal utterances on the above conversation can be found in sentences [2] and [4]. The refusal meaning is marked by the use of words nyanda', nda, dan te; all of the words were not used independently. The use of negation words on each refusal utterances is more meaningful if the words are used together with the other words in order to formulate specific speech acts of refusal. based on the background context, by using an indirect strategy, the declarative form of 
the sentence is meant as a prohibition against the speech partner.

\section{d) Indirect Strategy in Directive Speech Acts of Refusal in Malayan Bugis}

Refusal can be expressed by both direct and indirect utterances. Direct utterance is an utterance with literal meaning (Halim and Razak, 2014: 21). For example declarative utterance is used to give information, imperative utterance to command, while interrogative utterance to ask question. Meanwhile, indirect strategy is used to express contextual meaning. For example, interrogative utterance to express command, declarative utterance to refuse, and the others. The following is an example of indirect strategy used by female graduate to refuse the interlocutor.

Table 9. Direct Strategy in Directive Speech Acts of Command in Malayan Bugis

\begin{tabular}{|c|c|c|c|c|}
\hline No & Lo-In & Strategy Form & Bahasa Indonesia & English \\
\hline \multirow[t]{2}{*}{ [1] } & Lo & Jam berapa selesai? & Jam berapa selesai? & 'What time you finish?' \\
\hline & & Kutunggu maki nah? & Saya tunggu saja ya? & 'I'll wait for you, Ok? \\
\hline [2] & $\begin{array}{l}\text { In } \\
\text { (female) }\end{array}$ & $\begin{array}{l}\text { Sampe sore ka masuk, } \\
\text { tapi Iyee nanti saya liat } \\
\text { dulu bemana bisajie } \\
\text { tidak. }\end{array}$ & $\begin{array}{l}\text { Sampai sore saya masuk, } \\
\text { tapi nanti saya lihat dulu } \\
\text { bagaimana bisakah tidak. }\end{array}$ & $\begin{array}{l}\text { 'I've class till late afternoon. } \\
\text { Later I'll call you, if I can or } \\
\text { cannot go with you, OK?' }\end{array}$ \\
\hline
\end{tabular}

Context The interlocutor refuses the locutor's invitation by giving a statement.

Code STL/F.plk/13.03.17/02

Contextually, there is refusal utterance on data [9.2]. Although the meaning is refusal, there is the use of Bugis honorified vocatives as politeness markers to the interlocutor. Viewed from socio-cultural factor, it can be concluded that participants with the same social status and ethnicity can be the underlying reason in using indirect strategies (Göçtü \& Kir: 2014).

Imai, Kanero, and Masuda (2016: 70-71) state that language use is affected by the existing culture, and culture changes. Culture and language affect the way ones' word choice.

Based on social distance and social status, the level of intimacy between the locutor and interlocutor can be seen marked by the used of word 'iye' which means yes which is stated by older people to the younger or just simply the way to make the conversation intimate regardless the refusal uttered previously. This strategy is used to maintain the interlocutor's feeling by considering the existing culture.

Since the situation is not formal, the graduate tends to use word $n d a$ ' instead of tidak which both mean 'no.' This tendency shows how marker nyada' dan $n d a$ ' is used in speech acts of refusal. Besides, there is also the use of honorified vocative $k i$ which means we, with higher social sense, used to respect the interlocutor though in refusal context. Besides, contextual topic and participants affect the speech acts of refusal chosen by the graduate. 
e) Indirect Strategy in Directive Speech Acts of Prohibition in Malayan Manado

Below is one of directive speech acts of prohibition in Malayan Manado used among graduates. The meaning was uttered indirectly. Some examples of languages in developing countries are also related to the phenomenon of the use of local languages associated with politeness studios in Egypt, one of which is in the collection of ancient letters that have been for centuries related to the use of politeness in social relations, relationships between speech partners, academics, both directly and indirectly (Ridealgh, 2016, 245). The study of politeness phenomena in Late Egyptian is in its infancy, and like the majority of languages under review in this edition, Brown and Levinson's framework plays a fundamental role in analyzing examples of so-called 'politeness' because it offers the most complete assessment of interpersonal communicative acts. When dealing with a largely fragmented and interrupted dataset, it is not possible to apply other theories of politeness, such as the common sense approach voiced.

Below this is one form of indirect speech acts in the teaching-learning process in the classroom by considering the politeness scale.

Prohibition meaning is marked by statement odo, gaga nga pe suara e mar lebe bae ba diam which means that the interlocutor's voice is good. However, contextually, the use of indirect strategy makes the declarative sentence become a prohibition for the interlocutor to stop talking by adding mar lebe bagus leh badiam 'better you keep silent'. This means that the interlocutor's voice disturb her during a final exam.
The reason why the locutor made an implied prohibition because the locutor is woman and the interlocutor is man. Directive speech acts of prohibition used by woman is expressed cynically with blantant diction. The use of cynical expression was not used directly to quip instead to build conducive situation between them in order to achieve successful communication and did not disturb the others during a final exam (Filippova, 2015: 209; Hassan, Z.M, 2014).

The use of honorifics in the Bugis Malay language proves that the use of regional languages is influenced by age and who the speech partner is. The use of regional languages is used to show respect by students for lecturers. Previously, the form of politeness was first used by lecturers towards students by using indirect speech in the command. The age factor becomes the choice factor why local languages are used. If the speakers are peers. Then the choice of the form of regional languages used can be iyo (yes) in the Kaili and Malay Manado languages or it can even be in the form of murmurs, for example in the form of lingual expressions that are ok or good.

In addition, these things can also be known social groups, gender, age, ethnicity and social groups of speakers and speech partners. From the way of speaking someone can be known where someone came from, and where his ethnicity. No matter how far the changes in cultural outcomes will not change the existence of language (Hitchocock, 2017). The existence of language changes is influenced by many factors in a very fast vulnerable time. In the practical level, to understand this culture requires an emphasis on understanding relating to the ability to capture words and the ability to compose sentences, the ability to understand others, the ability to understand one's own emotions, and the ability to describe a concept of language. The 
goal is that students can perceive the language and culture in communication environment and express the concepts of (Ismadi, 2019).

Table 10. Direct Strategy in Directive Speech Acts of Command in Malayan Bugis

\begin{tabular}{|c|c|c|c|c|}
\hline No & Lo-In & Strategy Form & Bahasa Indonesia & English \\
\hline [1] & $\begin{array}{l}\text { Loc1 } \\
\text { (female) }\end{array}$ & $\begin{array}{l}\text { Odo, gaga nga pe suara } e \\
\text { mar lebe bagus leh } \\
\text { badiam. Te bisa torang } \\
\text { konsen ko bikin. }\end{array}$ & $\begin{array}{l}\text { Wah, bagus kamu punya suara ya } \\
\text { tetapi lebih bagus sepertinya } \\
\text { berdiam. Tidak bisa kami konsen } \\
\text { kamu buat }\end{array}$ & $\begin{array}{l}\text { Oh oh, your } \\
\text { voice is good, } \\
\text { but better if you } \\
\text { keep silent. We } \\
\text { cannot } \\
\text { concentrate, } \\
\text { you're too noisy. }\end{array}$ \\
\hline [2] & $\begin{array}{l}\text { In } \\
\text { (male) }\end{array}$ & $\begin{array}{l}\text { Iyo Fitri, te bisa sekali ba } \\
\text { sedu. }\end{array}$ & Iya Fitri, tidak bisa sekali bercanda. & $\begin{array}{l}\text { 'Yeah Fitri. Can } \\
\text { you be not so } \\
\text { serious for a } \\
\text { while?' }\end{array}$ \\
\hline [3] & $\begin{array}{l}\text { Lo } \\
\text { (female) }\end{array}$ & Akbar, kau sudah? & Akbar, sudah kamu? & $\begin{array}{l}\text { Akbar, you've } \\
\text { finished } \\
\text { task)? }\end{array}$ \\
\hline & $\begin{array}{l}\text { In } \\
\text { (male) }\end{array}$ & Iyo te lagi. & Iya tidak lagi (noisy) & Ok fine, no more \\
\hline & $\begin{array}{l}\mathrm{Pt} 2 \\
\text { (lecturer) }\end{array}$ & Ba ribut kamu. & Kumpul sekarang! & $\begin{array}{l}\text { You're so noisy, } \\
\text { submit (the } \\
\text { tasks) now! }\end{array}$ \\
\hline & Context & \multicolumn{3}{|c|}{$\begin{array}{l}\text { Uttered by a female graduate to her male friend who feels disturbed by his noise during } \\
\text { a final exam. }\end{array}$} \\
\hline & Code & \multicolumn{3}{|l|}{ STL/F.Irg/23.01.17/01 } \\
\hline
\end{tabular}

On the other hand, in any society there are various dialects. Inter-language or interdialect allows competition in the effort to occupy a special place in a particular society. If the socially diverse society is a political and geographical unit, language problems will arise. This language problem certainly involves the speech community. This diversity can also be found in India with India in the national language Hindi, although it has an alternative national language, namely English. However, Hindi was also established as the official language in the states of Himachal Pradesh, Delhi, Haryana, Uttar Pradesh, Chandigarh, Bihar, Madhya Pradesh and Rajashtan.
In addition, Indo-Aryan groups, such as Bengali, Gujarati, Marathi, Punjabi, have on their own languages. Also Dravidian groups, such as Telugu, Tamil and Malayalam. In this context, regional languages can be a bridge to get to know the culture and society in the area. In addition, learning also has the potential to teach elements (absorption words, formations) in local languages.

Indian Languages and one dialect, namely Manipuri, Assamese and Bengali and the Kakching dialect of Manipu Indian Languages and one dialect, namely Manipuri, Assamese and Bengali and the Kakching dialect of Manipuri. These languages are widely spoken across the North Eastern region of India. The overall 
phone recognition accuracies (Dutta \& Singh, 2017, 1-2).

\section{Conclusion}

There are both direct and indirect strategies used in Central Sulawesi higher education. In communicating by using the strategies, local languages such as Kaili, Malayan Bugis, and Malayan Manado are used. By using the communication strategies, the researchers find out three most used local languages. Those spoken languages are used by people in Palu specifically in academic context.

The local languages forms used are reflected on the use of directive speech acts strategies: (1) the use of directive speech acts strategy of request in Kaili is indicated by the use of Kaili pronoun such as Totuamo; Komiu (elder: person) and the use of nadoyo that means outstanding (the real meaning is 'wrong' or 'fool'), (2) directive speech acts strategy of suggestion in Malayan Bugis is marked by the use of suggestion in the form of verbs such as lebbirengngi that means better, vocative $n d i$ ' that means younger sister or brother, and vocative canti' that means beautiful or sweety. Those are used to show politeness and intimacy.

Another strategy is (3) commanding in Malayan Bugis directive speech acts strategy. It is shown by the use of $-k a$ ' and pronoun $t a$ to be more appropriate even though $-k o$ can be used in communicating with the people at the same age. Suggesting in Bugis direct strategy form found in the research is the use of lebbirengngi, (4) refusing in Melayu Manado directive speech acts is marked by the existence of the word nyanda' and jang that means prevention. The indirect strategies are (1) requesting in Melayu Manado indirect strategy in the form of question is indicated indirect utterance apa katu' depe nama? Which means what is the name of it? (2) suggesting in Melayu Bugis directive speech acts strategy is shown by the word lebbireng which means should. This makes the implicature which is actually harsh become polite and change the command into statement. (3) Indirect strategy used to command, prohibit, and refuse in Melayu Manado is signified by declarative negation marker koa' while quip with dang and ede as lexical costraints between intonation in declarative sentence, and (4) indirect strategy can also be found in Malayan Bugis in the form of refusal marked with vocatives $-k i$, iyee, and emphasis $-j i$.

\section{References}

Agus, N. (2014). Bentuk Sapaan Bahasa Bugis dalam Konteks Pragmatik Gender. Jurnal Sawerigading, 20(1), 1-13.

Alexander \& Okoli. (2017). Relating Communication Competences to Teaching Effectiveness: Implication for Teacher Education. Journal of Eduction and Practice, 8(10), 150-154.

Alwi, H., Dardjowidjojo, S., Lapoliwa, H., \& Moeliono, A.M. (2003). Tata Bahasa Baku Bahasa Indonesia. Jakarta: Balai Pustaka.

Darmojuono, S. (2011). Peran Etnopragmatis dalam Komunikasi Masyarakat Multikultural. Jurnal Linguistik Indonesia 29(1), 19-34.

Dutta., S.K., \& Singh L.J. (2017). An Analysis of Automatic Phone Recognition and Identification of a Few Languages from North Eastern India. Indian Journal of Sciences and Technology, 10(230), 1-5.

Filippova, E. (2014). Developing appreciation of Irony in Canadian and Czech Discourse. Journal of Pragmatics 74 (2014) 209-223.

Fomin, A.G., \& Yakimova, N.S. (2016). Communication Strategies in Conflict Discourse:Cross-Cultural Experimental 
Research. Procedia Social and Behavioral Sciences, 2016, 65-70.

Fontdevila, J. (2010). Indexes, Power, \& Netdoms: A Multidimensional Model of Language in Social Action. Peoetics 38 (2010) 587-609.

Göçtü, R. and Kir, M. (2014). Gender Studies in English, Turkish, and Georgian Languages in Terms of Grammatical, Semantic and Pragmatic Levels. Procedia-Social and Behavioral Sciences 158, 282-287

Halim A., N.A., and Razak A., N. (2014). Communication Strategies of Women Leader in Enterpreneurship. Procedia Social and Behavioral Sciences 118 (2014) 21-28.

Harman, R.M., Ahn., S., \& Bogue B. (2016). Reflective Language Teacher Education: Fostering Discourse Awareness Through Critical Performative Pedagogy. Teaching and Teacher Education 59 (2016) 228-238.

Hassan, Z.M. (2014). Language Contextualisation and Culture. Journal Procedia-Social and Behavioral Sciences 136 (2014) 31-35.

Hassanova, A. \& Rzayev, H. (2013). Pragmatics of yes/no indirect-respons (YNIRs). Journal Procedia Social and Behavioral Sciences 70, 1038-1048.

Hitchocock, R.K. (2017). Discontinuities in Ethnographic Time: A View from Africa. Journal of Antrhopological Archaeology 46 (2017) 12-27

Hiver, P., \& Whitehead, G. (2018). Sites of Struggle: Classroom Practice and the Complex Dynamic Entanglement of Language Teacher Identity. System Elsevier, 1-11.

Imai, M., Kanero, J., and Masuda, T. (2016). The Relation Between Language, Culture, and Thought. Current Opinion in Psychology Scient Direct (2016) 8: 70-77.

Ingram \& Elliot. (2016). A Critical Analysis of The Role of Wait Time In Classroom Interactions and The Effects on Student and Teacher Interactional
Behaviours. Cambridge Jurnal of Education 46 (1), 37-53.

Ismadi, H.D., 2019. Memahami Budaya Daerah sebagai Kunci Sukses dalam Pembelajaran BIPA. Badan Pengembangan Bahasa dan Perbukuan. Kementerian Pendidikan dan Kebudayaan. (http://badanbahasa.kemdikbud.go.id/l amanbahasa/artikel/2480/memahamibudaya-daerah-sebagai-kunci-suksesdalam-pemelajaran-bipa

Kashefi, H., Ismail, Z., \& Yusof, Y. M. (2010). Obstacles in the learning of two-variable functions through mathematical thinking approach. Procedia Social and Behavioral Sciences, $\quad 8(5), \quad$ 173-180. http://doi.org/10.1016/j.sbspro.2010.12 .024 .

Keckskes, I., Obdalova, O., Minakova, L., Soboleva, A. (2018). A Study of the Perception of Situasion-bound Utterances as Culture-Spesific Pragmatic Units By Russian Learners of English. System Elsivier, 76, 219232.

Keraf, Gorys.1991. Tata Bahasa Indonesia. Ende: Nusa Indah.

Kruiningen. J.F. (2013). Educational Design as Conversation: A Conversation Analyitical Perspective on Teacher Dialogue. Teaching and Teacher Education 29 (2013), 110-121

Lakoff, R. (2001). Language and Woman's Place. New York: Harper \& Row Publisher.

Liantada, C., M. (2018). Bringing Into Focus Multilingual Realities: Faculty Perceptions of Academic Language on Campus. Lingua Elsivier, 1-14.

Lohse., K., Gränefenhain, M., Behne, T., \& Racoczy, H. (2014). Young Children Understand the Nominative Implications Future-Directed Speech Acts. Plos One 9(1), 1-10.

Miles, B. M. \& Huberman, A. M.. (2014). Analisis Data Kualitatif. Penerjemah: Tjejep Rohendi Rohidi. Jakarta: UI Press. 
Mudiono, (2011). Kajian Etnografi Tindak Ilokusi Asertif Bahasa Indonesia dalam Pendidikan Informal. Jurnal Pendidikan dan Pembelajaran. 18, (2), 161-169.

Nasser, F., \& Alhija, A. (2017). Teaching in Higher Education: Good Teaching Through Students' lens. Studies in Educational Evaluation, 54, 4-12.

Ogunsiji, Y., Farinde, and Adebiyi. (2012). Language, Gender, and Culture. British Journal of Art and Social Sciences, 6(2). 202-210.

Pallawa, B.A. (2013). Function WorMt of Andio Language Viewed from Syntactical Aspect. Academic Journal of Interdiciplinary Studies, 2(2), 175185.

Peng, L., Xie, F. \& Cai, L. (2014). A Case Study OF College Teacher's Politeness Strategy in EFL Classroom., Theory \& Practice in Language Studies, 4(1), 110-115

http://ojs.academypublisher.com/index.

Praag, V.L., Stevens, A.J.P., Houtte, V.M. (2017). How Humor Makes or Breaks Student-Teacher Relationship: A Classroom Ethnography In Belgium. Teaching and Teacher Education 66, 393-401.

Prayitno, H.J., Kusmanto, H., Nasucha, Y., Rahmawati, L.E., Jamaluddin, N., Samsuddin, Ilma, A.A. (2019). The Politeness Comments on The Indonesian President Jokowi Instagram Official Account Viewed From Politico Pragmatics and The Character Education Orientation in The Disruption Era. Indonesian Journal on Learning and Advances Education, $1(2), 52-71$.

Rahman, M.Z., \& Jabar, M.A. (2014). Pengaruh Budaya Tempatan dalam Pembelajaran Bahasa Arab di Sekolah.
Procedia Social and Behavioral Sciences, 134, 373-381.

Ramlan, M. (2001). Ilmu Bahasa Indonesia: Sintaksis. Yogyakarta: Karyono.

Rideal, K. (2016). Polite like an Egyptian?

Case Studies of Politeness in the Late

Ramesside Letters. Journal of Politeness Research, 12(2), 245-266.

Sirkovic, N., \& Kovac, M. (2017). Attitude Towards Communication Skill Among Engineering Students. English Language Teaching, 10(3), 111-117.

Steadmen, A., Kayi-Aiydar, H., \& Vogel, S.M. (2018). From College Composition to ESL: Negotiating Professional Identities,New Understanding, and Conflicting Pedagogies. Sytem Elsivier, 76, 38-48.

Stranovskȧ, E., Munkova, D. Fräterova Z.,\& Duračkovã, B. (2013). Analysis of Politeness Speech Acts in Slovak and Foreign Languge Texts of Request in The Context of Cognitive Style. Jurnal Procedia-Sosial and Behavioral Sciences 82,764-769.

$\mathrm{Su}, \mathrm{H}$. (2017). Local Grammar Of Speech Act an Exploratoty Study. Journal of Pragmatics $1112017.72-83$.

Suparto. (2017). Ungkapan Linguistis Metafora Bahasa Indonesia dari Visual ke Kognisi (Perspektif Semantis Kognitif). Unpublished Dissertation: Program Doktor Linguistik Universitas Negeri Surakarta.

Tapio, E. (2018). Focal Social Action Throuhg Which Space is Configured and Reconfigured when Orienting to a Finnish Sign Language Class. Linguistics and Education 44 (2018), 60-79.

Yetiṣ \& Aslim, V. (2010). Virtual Classroom Site in French Written Expression Lesson: A Practice Sample. Procedia Social and Behavioral Sciences 2(2010) 446-470. 